PR-001＼cjkstart筋トレは最強のソリューションなの か?一筋トレ尺度の開発と 5 因子性 格尺度との関連性について一

○小野寺哲夫

(1東京保健医療専門職大学)

キーワード：筋トレ, プロテイン, テストステロン

テストステロン (著者) は『筋トレは最強のソリューションである』等 の書籍を通して，筋トレがもたらす恩恵について繰り返し述べている。

本研究の目的は, 日本人が筋卜レや食事制限等の健康習慣をどの程度 持っているか，抄よび筋トレに対してどのような認識をしているかを把 握するための効果的なツールとして, 筋トレ尺度を開発し因子分析を行 い，信頼性の検討を行うことである。

調查協力者は, 東京都内専門学校生54名, 質問紙法で, スポーツ経験, 筋卜レ尺度 (22項目)，5因子性格尺度：開放性因子，誠実性因子等を実 施した。

筋卜レ尺度の因子分析と信頼性係数（ $\alpha$ )の検討より，比較的きれいに 3 因子にまとまり，加えて十分な内的一貫性があることが示唆された。第 I 因子は，「筋トレのメリット因子」，第II 因子は，「筋トレと食事制限の 実践因子」，拈よび第皿因子は，「ソリューションとしての筋トレ因子」と 名付けられた。

次に，筋トレ尺度と 5 因子モデルの誠実性因子と開放性因子との間の ピアソンの相関係数 $(\mathrm{r})$ を算出したところ, 男性デー夕において, 筋卜 レ尺度と 5 因子モデルの誠実性因子との間で有意な正の相関が認められ た。

連絡先 E-mail：onodera408@tpu.ac.jp

注）＃印は日本心理学会会員以外であることを示す。

PR-002

\section{ポジティブ感情は死亡と疾患に影響 するか?一19年間の縦断研究—}

○中川 威, ${ }^{1,2}$, 西田裕紀子 ${ }^{1}$, 丹下智香子 ${ }^{1}$, 富田真紀子 ${ }^{1}$, 大塚 礼, ${ }^{1, \#}$, 安藤富士子 ${ }^{1,3}$, 下方 浩史 ${ }^{1,4}$

(1国立長寿医療研究センター, ${ }^{2}$ 日本学術振興会, ${ }^{3}$ 愛知淑德大学, ${ }^{4}$ 名古屋 学芸大学)

キーワード：情動, 健康, 幸福感

本研究では, ポジティブ感情が死亡と疾患罹患を予測するか検討する ことを目的とした。NILS-LSA 第 1 次調查参加時をベースラインとし， 19 年間追跡したデータを用いた。説明変数はポジテイブ感情（CES-D 抑う つ尺度下位尺度), 目的変数は全死亡, 死因別死亡 (循環器疾患 [心疾 患・脳血管疾患 $],$ がん), 疾患罹患 (心疾患, 脳血管疾患, がん, 糖尿 病，高血圧), 統制変数はネガティブ感情, 年齢, 性別, 教育歴, 婚姻状 況, 既往歴（前述の 5 疾患）, 握力, 歩行速度, 主観的健康感, 飲酒, 喫 煙，身体活動とした。分析対象者は，全死亡を除き，ベースライン時に 各目的変数の疾患に罹患していない者であった（全死亡： $\mathrm{N}=2,033$ ； 40-80歳; 女性 $49.5 \%) 。 C o x$ 比例ハザード回帰分析を行った結果, ポジ ティブ感情は死亡と疾患罹患を予測しなかった。人口学的変数（年齢, 性 別, 教育歴) がポジティブ感情と健康の関連を調整するか検討した結果, 男性では，ポジティブ感情が 1 標準偏差高いとがん罹患りスクが低かっ た（ハザード比 $=0.55,95 \%$ 信頼区間: $0.38-0.80)$ 。ポジティブ感情は, 特定の状況や健康指標でのみ, 有益な効果を有することが示唆された。今 後,これらの機序を精緻に検討すべきである。

連絡先 E-mail : ntakeshi@ncgg.go.jp

\title{
PR-003＼cjkstart生活実感を伴うストレス経験の簡易 な分類の提案
}

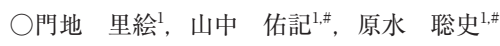

('花王)

キーワード : ストレス, 健康, 感情

本研究では，生活実感に根差した簡易なストレス分類を目指し，20～ 69 歳の日本人成人男女 300 名を対象に, 複数の既存のストレス評価尺度へ の回答を求めるインターネット調查を実施した。調查票は, 自由回答質 問に加え，職業ストレス簡易調查票（下光，2004）を含む既存の尺度と 感情や身体症状を尋祸る, 選択式回答の113問から構成した。このうち, ストレッサーやストレス状況に対する主観的な認知評価に関する33問へ の回答を抜粋し, 因子分析（最尤法, Promax 回転）を適用した。結果, 5 因子解を採用し (累積説明率 $49.7 \%$ )，各因子を，「1，オーバーロー ド（へとへと）因子」,「2．神経疲れ（ぴりぴり）因子」,「3，人間関 係（しくしく）因子」,「4，やりがい（いきいき）因子」, そして「5. コントロール（すいすい）因子」と命名した。さらにクラスター分析に よって，回答者の分類を行い，5つのクラスターを分類した。以上から， 日常で経験しがちなストレス状況を，5つのクラスターの示す状沉から 簡易に示すことのできる可能性を提言した。

連絡先 E-mail：monchi.rie@kao.com

\section{PR-004＼cjkstart地域在住フレイル高齢者の総死亡リ スクに対するソーシャルサポートの 緩衝効果：縦断的検討}

○下智香子 ${ }^{1}$, 西田裕紀子 ${ }^{1}$, 富田真紀子 ${ }^{1}$, 中川 威 ${ }^{1,2}$, 大塚 礼1,*, 安藤富士子 ${ }^{1,3}$, 下方 浩史 1.4 , 荒井 秀典1.,

(1国立長寿医療研究センター, ${ }^{2}$ 日本学術振興会, 恶知淑德大学, ${ }^{4}$ 名古屋 学芸大学)

キーワード：身体的フレイル，ソーシャルサポート，死亡

フレイルは高齢者の健常と要介護・死亡の中間の状態であり，その進行 を抑制する要因の解明が必要である。本研究はフレイル高齢者の死亡リ スクに対するソーシャルサポート [SS］の緩衝効果を検討した。「国立長 寿医療研究センター・老化に関する長期縦断疫学研究」の第2-7次調查の 65歳以上参加者で, 下記データがあり, フレイルの CHS 基準 5 項目（一

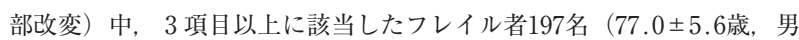
性 $38.6 \%$, 追跡期間 $8.7 \pm 4.4$ 年）を解析対象とした（初該当時がベース ライン $[\mathrm{BL}])$ 。死亡情報（2017.12.31時点）は人口動態統計の二次利用 に基づいた。 $\mathrm{SS}$ は BL 時の家族内/外からの 3 種のサポート（情緒的／ 手段的／ネガティブ）を測定し（野口，1991），各下位尺度平均值に基づ き低/高群に群分けした。各SSについて, BL 時の性・年齢・健康／社 会背景指標・フレイル項目該当数を調整し，低群を基準として高群の死 亡リスクを Cox 比例ハザードモデルにより推定した。その結果，家族の ネガティブサポートが高い場合に死亡リスクが高く（ハザード比：1.72, 95\% CI ：1.05-2.82)，フレイル者にとって家族内の望ましくないサポー 卜（非難，過度の支援など）が悪影響を持つ可能性が示唆された。 